\title{
Corporate Governance and Bank Performance: Global Financial Crisis 2008
}

\author{
Zaitul $^{1}$, Zerni Melmusi ${ }^{2}$ and Desi Ilona ${ }^{2, *}$ \\ ${ }^{1}$ Faculty of Economics and Business, Universitas Bung Hatta, Padang, Indonesia \\ ${ }^{2}$ Faculty of Economics and Business, Universitas Putra Indonesia, YPTK Padang, Indonesia
}

\begin{abstract}
This research examine the role of Corporate Governance on bank performance; pre and during global financial crisis 2008. Using 2006 to 2009 data of 27 banks listed in Indonesia Stock Exchange is as research sample. Board, Family and Foreign Ownership as an internal Corporate Governance mechanism and Audit Quality is a proxy for external mechanism. Moderated Regression Analysis is applied. The result shows that there is no role of Corporate Governance in pre-global financial crisis. In addition, this study documented that the role of Corporate Governance practices is poor during global financial crisis 2008, especially 2009.

Research limitations: Internal Corporate Governance mechanism does not use board or audit committee characteristics, such as board independent and audit committee financial expertise. Bank should strengthen Corporate Governance system while financial crisis come and uniqueness of Indonesia Corporate Governance system enrich Corporate Governance literature. This research is a significant addition to Corporate Governance literature because of using data from unique business environment and Corporate Governance system as well as in global financial crisis.
\end{abstract}

Keywords: Corporate Governance, bank performance and Global Financial Crisis.

\section{INTRODUCTION}

Until now, the term of Corporate Governance has been a critical topic around the worlds, including Indonesia (Jung, 2013; Aldamen and Duncan, 2016; and Darmadi, 2016). How to build the better relationship between agent and principal in order to enhance a better company performance is an objective of Corporate Governance. However, this goal cannot be achieved when financial crisis happen (Chia et al., 2007). Many companies collapsed when global financial crisis occur in 2008, especially in US, such as Lehman Brothers Holding Inc. Weak of Corporate Governance is believed as major contribution for financial enterprises downfall in crisis 2008 (Haspeslagh, 2010 and Kowalewski, 2016). This is also supported by researches, such as Srivastava (2015) and Orazalin et al. (2016). This crisis also influences other countries, including Indonesia.

The issue of Corporate Governance was introduced by Berle and Means (1932), and also Adam Smith (1759) who explained Theory of Moral Sentiment. However, Monk and Minows (2008) define the Corporate Governance as a set of relationship between shareholders, Board of Directors and Board of Commissioners in manage, control, and monitor the company's operation in order to increase bank performance. The better Corporate Governance

*Address correspondence to this author at the Faculty of Economics and Business, Universitas Putra Indonesia YPTK, Padang, Indonesia; Tel: +62751-776666, Fax: +62-751-71913, E-mail: desiilona@upiyptk.ac.id practices give a significant impact on quality and reliable of financial information (Husnin and Nawawi, 2016) and, finally improve the company performance (e.g., Baysinger \& Butler, 1985; Bozec 2005; Haniffa \& Hudaib, 2006; and Darmadi, 2016). There are two mechanisms on Corporate Governance that are internal and external mechanisms. The external mechanism is external auditor, the rule and regulation, and managerial labor market. Furthermore, the internal mechanism consists of Board of Commissioners, Board of Directors, structure of ownership, compensation of Board and financial structure (Denis, 2001 and Daily et al., 2003). The internal Corporate Governance will become great factor to reduce the agency problem when the country follow the French Civil law; worse protection for shareholder and less effective of external mechanism of Corporate Governance (La Porta et al., 1998 and Nuryanah and Islam, 2011). According to Jensen and Meckling, (1976), better implementation of Corporate Governance will reduce agency problem and finally enhance shareholders' desires.

Using 5.829 Korean companies, Joh (2003) only focus on the effect of Corporate Governance on company performance before the financial crisis in 1997. While, Srivastava (2015) uses 164 non-financial listed companies of the Bombay Stock Exchange-200 index to examine the effect of Governance structure on company performance during global financial crisis in 2008. Aldamen and Duncan (2016) investigate the role of Corporate Governance on company performance when global financial crisis occur in 2008. Almutairi (2013), and Husnin and Nawawi, (2016) only focus on 
the effect of Corporate Governance on audit quality. Furthermore, there is limited prior work that investigate the role of Corporate Governance on bank performance, audit quality as moderating variable; pre and during global financial crisis in 2008. Thus, this study is focused on the role of Corporate Governance on bank performance, audit quality as moderating variable; pre (2006 and 2007) and during (2008 and 2009) global financial crisis. The Corporate Governance variable is measured by board ownership, family ownership, foreign ownership, and audit quality.

Indonesia is one of the countries that adopt the Continental European system (Zaitul and Ilona, 2018, 2019). The issue of Corporate Governance in Indonesian is different with other countries who adopt the Continental European system in several ways. First, Indonesia has modified this system where as Board of Commissioners and Board of Directors is chosen by general meeting of shareholders. Second, more than fifty percent companies listed in Indonesia are owned by family and foreign ownership. It is supported by Darmadi (2016) who states that Indonesia is one of country with higher ownership concentration and family ownership. Thus, it needs the better quality audit to reduce agency problem trough monitoring mechanism. Until now, there is limited prior study to test the role of Corporate Governance and bank performance, pre and during global financial crisis in 2008, particularly Indonesia. The other reasons to choice this topic because some companies listed on Indonesia Stock Exchange (IDX) still have poor performance. According to Abidin et al. (2011), they find that around $15 \%$ Indonesian listed companies have a negative Return on Asset (ROA). In addition, Nuryanah and Islam (2011) conclude that the implementation of good Corporate Governance in Indonesia still low.

Global financial crisis 2008 had a significant impact on Indonesia business environment, especially banking industry. One of large bank, namely Century Bank, was defaulted on several large payments and declared insolvency by the Indonesia's Financial Sector Stability Committee (Komite Stabilitas Sektor Keuagan-KSSK) in late October 2008. Finally, Deposit Insurance Agency (LPS) was taking action and totally 6.7 trillion Rupiah or almost US\$700 Million had been injected to Century Bank over period of nine months. This scandal indicates that there is a weak practice of corporate governance during the global financial crisis.

This research is constructed as follow. The next part explains theoretical aspect and hypothesis development. It is followed by research method. The next section is result and discussion. The final section discusses about conclusion of the study.

\section{THEORETICAL ASPECT AND HYPOTHESIS DEVELOPMENT}

Corporate Governance is a set of system for overseeing and monitoring the agent to perform based on shareholder's interest (Jung, 2013). In general, there are two system in Corporate Governance that are Anglo-Saxon and Continental European system. The main different between both systems are type of board. Company is managed and controlled only single Board of Directors (Executive and non-Executive Board) in Anglo-Saxon system. However, there are two types of board in Continental European system, whereas company is managed by Board of Directors and Board of Directors is monitored by Board of Commissioners. Corporate governance has been playing a significant role in developing the financial market and company performance (La Porta et al., 2000). The poor practice of corporate governance would impact on the performance of companies. Together with weak financial market control, the majority shareholder would expropriate the right of minority shareholder by using the affiliate transaction due to the declining of return in capital market (Lemmon and Lins, 2003).

There are several theories that explain about Corporate Governance and bank performance that are agency theory (Jensen and Meckling, 1976) and stewardship theory (Davis et al., 1997). Agency theory posits that the agent cannot be trust. Thus, they must be controlled and monitored to do better action. In contrast, stewardship theory believes that the agent can be trusted to perform based on principal's interest. In addition, principal can expect the agent could maximize their wealth. According to Grove et al. (2013), strongly of Corporate Governance mechanism could align the interest of principal and agent. In addition, Corporate Governance mechanism can be classified into two; internal and external mechanisms. The internal mechanism is ownership, Board of Commissioners, Board of Directors and Shareholders (Weir et al., 2002). While, the eksternal mechanism is from rule and regulation, external auditor, and managerial labor market (Byrd et al., 1998).

\subsection{Ownership Structure}

Ownership structure consists of ownership concentration, institutional, government, foreign and 
family ownership. Ownership concentration has benefit to effective monitor the agent in order to reduce the agency problem (Demsetz and Lehn, 1985). However, Ownership concentration also has big power in the decision making and it makes poor the implementation of Corporate Governance practices (Jung, 2013). Indonesia has modified the Corporate Governance system that controlling shareholders have power to choice and dismiss both boards. As a result, they may fail to choice a better Board of Commissioners and Board of Directors. Sometimes, they elect board who has a relationship with them. This condition creates a potential manner for controlling shareholders to control that board for their own interest (Van-Essen et al., 2012). Thus, it will impact on reducing the bank performance. The risk of cost increasing is inclining if corporate governance rule is broken, such as the rule of one-share one vote. Therefore, voting right of a shareholder exceed the right of company cash (Faccio dan Lang, 2002).

Liu and Magnan (2011) conclude that the difference on voting right and cash flow right would reduce the company value in the normal condition. In addition, there is a tendency that majority shareholders would expropriate the minority shareholder right (Lemmon and Lins, 2003). In fact, this activity would increase during the financial crisis. During crisis, the majority shareholders will seek ways to minimalize their investment risk by taking benefit. Another word, majority shareholder action would create loss for minority shareholders and creditors. However, some majority shareholder does not have an intention to do so. In fact, they create the policy that supports company to be good condition and help companies by providing an economic resource from their own pocket.

Previous studies that investigate the role of ownership structure show various result (e.g., Lodh et al., 2014 and Gul et al., 2010).Using 395 Indian familycontrolled listed companies, Lodh et al. (2014) investigate the effect of family ownership on innovation during the period of 2001-2008. They find that the family ownership has a positive and significant impact on innovation. Opposite to Lodh et al., (2014), Gul et al., (2010) find that there is insignificant impact between foreign ownership, audit quality on stock return.

\subsection{Audit Quality}

Financial crisis could impact on uncertainty and reduce bank performance (Chia et al., 2007). Thus it need external auditor who have a better quality. In order to maintain the quality of audit, auditor conducts quality control in proses audit. Quality control consists of method used to ensure the company accountable to its stakeholders. According to Arens (2009), there are five element of quality control that published by Internasional Federation of Accountants (IFAC) that is independence, integrity and objectivity, personnel management, acceptance and continuation of clients engagements, engagements performance, dan monitoring. The element of quality control expected could increase audit quality of external auditor or certified public accountant (CPA) and reliable of accounting information.

Defond and Jiambalvo (1993) argue that big audit firm would face with higher operation cost. Besides, the big audit firm tend better to detect misstatement and frauds. DeAngelo (1981) conclude that the Big Audit firm have a strong reason to come out with higher quality of audit report and therefore, audited company tend to have a higher quality financial report. Further, reliability of financial report would increase. Besides, company which is audited by Big-4 audit firm would be perceived that opportunistic behavior of management tends to reduce and it, therefore, will minimalize the agency cost. Finally, it would increase the performance of company. Wu (2012) concludes companies audited by Big-4 audit firm could increase audit fee and finally reduce bank performance.

Corporate governance is measured by ownership concentration (board, family and foreign ownership) and audit quality. These variables are representing both internal and external Corporate Governance mechanism. Firm with family ownership may want to compensate the impression of weak of corporate governance by appointing a high-quality auditor (Husnin and Nawawi, 2016). Low quality of corporate governance would impact to the small size of independent directors (Hashim, 2011) and finally, low level of transparency (Darmadi and Sodikin, 2013). Company with foreign ownership is controlled more on management due to the separation of owner and management (Nelson and Mohamed-Rusdi, 2015). They add that foreign shareholders tend to demand high quality of audit. However, the companies with higher board ownership demand for less audit work and the other word, it requires the low audit quality (Nelson and Mohamed-Rusdi, 2015). Based on the discussion above, this paper develops two hypotheses as follow. 
H1: The role of Corporate Governance is predicted weak before global financial crisis (2006 and 2007).

H2: The role of Corporate Governance is predicted poor during global financial crisis (2008 and 2009).

\section{RESEARCH METHOD}

The object of this study is banks listed in the Indonesia Stock Exchange during the 2008 global crisis. Banks are selected as an object of this research due to the uniqueness of this industry like sensitive to the economics conditions or called an interest sensitive industry (Really and Brown, 2003). Beside, Bank is a heavily regulated industry in order to have higher responsibility for its customer and reducing risk. Banks have the complexity of activities as well as higher asymmetry of information. In addition bank plays a significant role in economic system as intermediaries' institutions. In addition, banks are claimed as highly leverage firm since bank deposit customer money. The purposive sampling method is used because several variabels are disclosure in nature. this study use a secondary data from several sources, such company website, Indonesia Stock Exchange website and other sources. There are four types of variable used in this study that are dependent, independent, moderating and control variable. Bank performance as dependent variabel is measured by Return on Asset (ROA), whereas the Corporate Governance as internal mechanism are measured by board ownership, family and foreign ownership (measured by percentage). Meanwhile, moderating variable is audit quality (Big-4 or non Big-4) is used for proxy of external Corporate Governance mechinism. Finally, this study also use several control variables, such as bank size (measured by total asset), bank age, bank growth (measured by sales in the current year less in the previous year divided by sales in last year) and bank leverage (debt to asset as proxy).

To answer the hypotheses, this research uses moderated regression analysis (MRA) due to the existence of the moderating variable. The prior study also implies MRA, such as Arora and Dharwadkar (2011). The research model are listed below.

$\mathrm{BP}=\alpha+\beta_{1} \mathrm{BO}_{\text {it }}+\beta_{2} \mathrm{FaO}_{\text {it }}+\beta_{3} \mathrm{FO}_{\text {it }}+\beta_{4} \mathrm{BS}_{\text {it }}+\beta_{5} \mathrm{BA}_{\text {it }}+$ $\beta_{6} B G_{i t}+\beta_{7} B L_{i t}+e$

$\mathrm{BP}=\alpha+\beta_{1} \mathrm{BO}_{\mathrm{it}}+\beta_{2} \mathrm{FaO}_{\mathrm{it}}+\beta_{3} \mathrm{FO}_{\mathrm{it}}+\beta_{4} \mathrm{BS}_{\mathrm{it}}+\beta_{5} \mathrm{BA}_{\mathrm{it}}+$ $\beta_{6} B G_{i t}+\beta_{7} B L_{i t}+\beta_{8} A Q_{i t}+e$
$\mathrm{BP}=\alpha+\beta_{1} \mathrm{BO}_{\mathrm{it}}+\beta_{2} \mathrm{FaO}_{\mathrm{it}}+\beta_{3} \mathrm{FO}_{\mathrm{it}}+\beta_{4} \mathrm{BS}_{\mathrm{it}}+\beta_{5} \mathrm{BA}_{\mathrm{it}}+$ $\beta_{6} \mathrm{BG}_{\mathrm{it}}+\beta_{7} \mathrm{BL}_{\mathrm{it}}+\beta_{8} \mathrm{AQ}_{\mathrm{it}}+\beta_{9} \mathrm{BO} \mathrm{BQ}_{\mathrm{it}}+\beta_{10} \mathrm{FaOxAQ_{it }}+$ $\beta_{11} F O x A Q_{i t}+e$

Where as

$$
\begin{aligned}
& \mathrm{BP}=\text { Bank Performance } \\
& \mathrm{BO}=\text { Board Ownersip } \\
& \mathrm{FaO}=\text { Family Ownership } \\
& \mathrm{FO}=\text { Foreign Ownership } \\
& \mathrm{BS}=\text { Bank Size } \\
& \mathrm{BA}=\text { Bank Age } \\
& \mathrm{BG}=\text { Bank Growth } \\
& \mathrm{BL}=\text { Bank Leverage } \\
& \mathrm{AQ}=\text { Audit Quality }
\end{aligned}
$$

The analysis procedure is begun with normality test and followed by multicollinearity and heteroscedasticity. Finally, it reggress the data using MRA procedures. By utilizing the $F$ statistic, $R$ square and $p$ value to see whether the model is fit, the power of the model and to reject or accept the alternative hypotheses.

\section{RESULT AND DISCUSSION}

\subsection{Research Findings}

As mention in the previous session, this article use the banking industry listed in Indonesia Stock Exchange with the population of 29 banks. Due to the unavaibility of data consistently, the final sample is 27 banks from 2006 to 2009 period.

Table 1 shows the statistic descriptive of variables. The ROA as a measurement for bank performance has a mean value of $2,7 \%$ with minimal and maximal value of $-2.7 \%$ and $22.4 \%$, respectively. ROA means value of $2.7 \%$ indicates that the bank performance during 2006 2009 was low. In addition, board ownership mean value is $2.4 \%$. The minimum and maximum values of board ownership are $0 \%$ and $54.2 \%$, respectively. Further, the mean value of the family ownership is $18 \%$ with the maximum and minimum are $78.9 \%$ and $0 \%$ accordingly. Meanwhile, the foreign ownership means value is $33,1 \%$ with minimum and maximum value of $0 \%$ and $80.7 \%$ respectively. External Corporate Governance mechanism which is measured by type of 
Table 1: Statistic Descriptives

\begin{tabular}{|c|c|c|c|c|c|}
\hline Variabel & $\mathbf{N}$ & Min & Max & Means & SD \\
\hline BP (\%) & 27 & -2.7 & 22.4 & 2.7 & 4.6 \\
\hline BO (\%) & 27 & 0.0 & 54.2 & 2.4 & 10.4 \\
\hline $\mathrm{FaO}(\%)$ & 27 & 0.0 & 78.9 & 18.0 & 25.8 \\
\hline FO (\%) & 27 & 0.0 & 80.7 & 33.1 & 30.2 \\
\hline$A Q$ (dummy) & 27 & 0.0 & 1,0 & 0.6 & 0.5 \\
\hline BS (Rp.Million) & 27 & 46,432 & 268.102 .379 & 47.901 .007 & 77.474 .945 \\
\hline BA (Year) & 27 & 5.5 & 112.5 & 38.9 & 27.6 \\
\hline BG (\%) & 27 & -51.1 & 40.5 & 14.6 & 16.2 \\
\hline $\mathrm{BL}(\%)$ & 27 & 9.9 & 94.8 & 77.9 & 22.8 \\
\hline
\end{tabular}

audit firm used by bank indicates that $60 \%$ of banks was audited by Big-4 audit firm and the rest is non Big4. Average value of bank size is Rp. 47.901.007 million with the minimal and maximal value are Rp.46.432 million Rp. 268.102.379 million, respectively. Bank age average is 38.9 years with minimum and maximum age are 5.5 and 112.5 years, respectively. Bank growth is measured by earning growth and it has a mean value of $14.6 \%$ with minimum and maximum growths are $51.1 \%$ and $40.5 \%$. Finally, bank leverage average is $77.9 \%$ with minimum and maximum leverage is $9.9 \%$ and $94.8 \%$, respectively.

Procced to the classical assumption test, the result of normality test and its transformation is shown in Table 2. Result of the normality test indicates that only Family Ownership (FaO) and Foreign Ownership (FO) are normal using the J-Bera Test and the rest are not normal. In addition, variables are not normal transformed to the log natural (Ln) and square. Having transformed, the J-Bera test is run and the result show that all not normal variables become normal due to the p-value of $\mathrm{J}$-Bera greater than 0.05 .

Second classical assumption test is multicollinearity. The model is assumed that free of multicollinearity problem. It means that there is no relationship between independent variables. In addition, tolerance and VIF value are applied to see whether any such problem. The result shows that there is no multicollinearity problem (see Table 3 ) due to the value of VIF and Tolerance (less than 10 and 1 respectively).

The third classical assumption is heteroscedasticity. Blue model assume that there is no relationship between independent variables and error. There are several tests available to investigate this problem, such as Glejzer and White test (White, 1980). In this case, we use the LM test and the result is shown in Table 4 below. P-value of Bank performance is greater than 0.05 and it can be concluded that there is no heteroscedasticity problem. Autocorrelation is not

Table 2: Results of Normality and Transformation

\begin{tabular}{|c|c|c|c|c|c|c|c|}
\hline \multirow{2}{*}{ Variable } & \multicolumn{2}{|c|}{ Normality } & \multirow{2}{*}{ Result } & \multicolumn{4}{|c|}{ Transform } \\
\hline & J-Bera & $P$ value & & & J-Bera & $P$ value & Result \\
\hline \multirow{2}{*}{$\begin{array}{l}\text { BP } \\
\text { BO }\end{array}$} & 168.64 & 0.00 & Not normal & Ln & 0.53 & 0.78 & \multirow{2}{*}{$\begin{array}{l}\text { normal } \\
\text { normal }\end{array}$} \\
\hline & 629.59 & 0.00 & Not normal & Ln & 0.94 & 0.62 & \\
\hline $\mathrm{FaO}$ & 4.48 & 0.11 & Normal & & & & \\
\hline FO & 2,79 & 0.25 & Normal & & & & \\
\hline BS & 20.54 & 0.00 & Not normal & Ln & 0.53 & 0.77 & normal \\
\hline BA & 6.88 & 0.03 & Not normal & Ln & 0.34 & 0.84 & normal \\
\hline BG & 104.63 & 0.00 & Not normal & Ln & 4.27 & 0.12 & normal \\
\hline$B L$ & 13.66 & 0.00 & Not normal & Square & 6.54 & 0.04 & normal $^{*}$ \\
\hline$A Q$ & \multicolumn{2}{|c|}{ Dummy } & & & & & \\
\hline
\end{tabular}

Note: * normal at a 0,025. 
applied here because of regression is run per year data.

Table 3: Results of Multicollinearity

\begin{tabular}{|c|c|c|}
\hline Variable & Tolerance & VIF \\
\hline \hline BP & 0.64 & 1.56 \\
\hline BO & 0.35 & 2.82 \\
\hline FaO & 0.45 & 2.23 \\
\hline FO & 0.64 & 1.57 \\
\hline BS & 0.77 & 1.31 \\
\hline BA & 0.12 & 1.63 \\
\hline BG & 0.68 & 1.46 \\
\hline BL & 0.51 & 1.97 \\
\hline
\end{tabular}

Table 4: Results of Heteroscedastisity

\begin{tabular}{|c|c|c|}
\hline & BP & Result \\
\hline \hline LM test & 4.82 & \multirow{2}{*}{ No multicollinearity problem } \\
\hline P value & 0.68 & \\
\hline
\end{tabular}

\subsection{The Role of Corporate Governance on Bank Performance (Pre and During Crisis 2008)}

This paper aims to investigate the role of Corporate Governance on bank performance; pre and during global financial crisis. The analysis is segmented into three type model. Each model is analyzed from precrisis (2006 and 2007), during crisis (2008 and 2009) and the other model using all data from 2006 to 2009 . The regression result of three models is (MRA) demonstrated in Tables 5, 6, and $\mathbf{7}$. The result of first model is presented in Table $\mathbf{5}$. Based on Table $\mathbf{5}$, it can be seen the result of this study as classified into precrisis (2006 and 2007), during-crisis (2008 and 2009), and average (2006-2009). By using 2006 data, it can be concluded that the model is fit due to the F-statistic (0.110) greater than $10 \%$. Meanwhile, the R-square indicate that $36.30 \%$ variation of bank performance is explained by independent variables and the rest is determined by other variables which is not included in this model. There are no significant Corporate Governance variables that partially influence the bank performance. However, one of the control variables, namely bank leverage, has a negatively significant with the bank performance. Thus, it means that the higher the leverage the worse the bank performance.

As can be seen on Table 5, the result by using the 2007 data indicates that the model is feasible due to the F-significant is lower (F-sig 0.08) than $10 \%$. Meanwhile, the R-square of model is $44.90 \%$ which indicate that variation in bank performance is explained $44.90 \%$ by independent variables. This study finds no significant the role of the Corporate Governance

Table 5: Results of MRA 1 Regression

\begin{tabular}{|c|c|c|c|c|c|c|c|c|c|c|}
\hline \multirow[t]{2}{*}{ Variable } & \multicolumn{2}{|c|}{$\begin{array}{l}\text { Pre-crisis } \\
2006\end{array}$} & \multicolumn{2}{|c|}{2007} & \multicolumn{2}{|c|}{$\begin{array}{l}\text { During- crisis } \\
2008\end{array}$} & \multicolumn{2}{|c|}{2009} & \multicolumn{2}{|c|}{ All data } \\
\hline & Coef & t-sta & Coef & t-sta & Coef & t-sta & Coef & t-sta & Coef & t-sta \\
\hline Constant & 10.20 & 4.042 & 9.580 & 4.100 & 11.280 & 3.410 & 14.260 & 4.260 & 12.460 & 4.860 \\
\hline BO & -0.03 & -0.411 & 0.060 & 0.810 & 0.050 & 0.400 & -0.080 & -0.760 & 0.050 & 0.610 \\
\hline $\mathrm{FaO}$ & -0.01 & -0.333 & -0.060 & -1.800 & -0.080 & -1.430 & -0.050 & -0.950 & -0.090 & $-2.010^{*}$ \\
\hline FO & 0.00 & 0.086 & -0.020 & -0.720 & -0.040 & -1.070 & -0.070 & $-1.750^{*}$ & -0.060 & $-1.840^{*}$ \\
\hline BS & 0.00 & -0.061 & 0.000 & 0.070 & 0.000 & -0.520 & 0.000 & 0.000 & 0.000 & -0.390 \\
\hline BA & -0.03 & -1.108 & -0.020 & -0.700 & 0.020 & 0.630 & 0.010 & 0.240 & -0.010 & -0.023 \\
\hline BG & 0.02 & 0.462 & 0.080 & $2.880^{\star * *}$ & 0.140 & $3.100^{* * *}$ & 0.230 & $3.690^{* * *}$ & 0.220 & $4.052^{* * *}$ \\
\hline $\mathrm{BL}$ & -0.08 & $-2.630^{* *}$ & -0.070 & $-2.290^{\star *}$ & -0.110 & $-2.160^{\star *}$ & -0.140 & $-2.890^{\star * *}$ & -0.120 & $-3.230^{\star * *}$ \\
\hline $\mathrm{N}$ & \multicolumn{2}{|c|}{27} & \multicolumn{2}{|c|}{27} & \multicolumn{2}{|c|}{27} & \multicolumn{2}{|c|}{27} & \multicolumn{2}{|c|}{27} \\
\hline R Square & \multicolumn{2}{|c|}{0.363} & 0.449 & & \multicolumn{2}{|c|}{0.472} & \multicolumn{2}{|c|}{0.553} & \multicolumn{2}{|c|}{0.588} \\
\hline $\begin{array}{c}\text { Adj R } \\
\text { Square }\end{array}$ & \multicolumn{2}{|c|}{0.129} & 0.246 & & \multicolumn{2}{|c|}{0.278} & \multicolumn{2}{|c|}{0.388} & \multicolumn{2}{|c|}{0.437} \\
\hline F statistic & \multicolumn{2}{|c|}{1.550} & 2.211 & & \multicolumn{2}{|c|}{2.431} & \multicolumn{2}{|c|}{3.352} & \multicolumn{2}{|c|}{3.880} \\
\hline $\mathrm{F}$ sig & \multicolumn{2}{|c|}{0.211} & 0.080 & & \multicolumn{2}{|c|}{0.059} & \multicolumn{2}{|c|}{0.017} & \multicolumn{2}{|c|}{0.009} \\
\hline
\end{tabular}

Note: ${ }^{*},{ }^{* \star}$, and ${ }^{* \star *}$ indicate that a significant at $10 \%, 5 \%$, dan $1 \%$ level. 
variables on bank performance. In addition, this result is the same with previous year of this data (2006). Thus, it can be concluded that there is no significant effect Corporate Governance on bank performance; pre financial crisis. However, two control variables have a significant relationship with bank performance: bank growth and bank leverage. Bank growth has a positive effect which means that the higher the bank growth the higher the bank performance. In contrast, the bank leverage has a negative relationship with bank performance. This result is the same with the 2006 data.

The second model uses the 2008 and 2009 data (during financial crisis). From the Table $\mathbf{5}$ it can be showed that the fitness of model is fit due to the $F$ significant is lower $(0.059)$ than $10 \%$. Further, the Rsquare of this model is $47.20 \%$ which means that the variation of dependent variable is explained $47.20 \%$ by independent variables and the rest is determined by other variable in 2008. Therefore, there is no relationship between Corporate Governance variables and bank performance during financial crisis. In addition, two control variables ( $B G$ and $B L$ ) have a significant effect on bank performance. Bank growth has a positive relationship with the bank performance. However, bank leverage has a negative and significantly effect on bank performance.

In 2009, the result shows that the model is feasible because of the $\mathrm{F}$ significant is lower (1.7\%) than $5 \%$. In addition, R-square is $55.30 \%$ which means that variation of bank performance is explained $55.30 \%$ by the independent variables and the rest is explained by other variables which is not included in this model. Two Corporate Governance variables do not influence bank performance. Only one of Corporate Governance variables have a significant and negatively relationship with bank performance that are foreign ownership at $10 \%$. It means that the higher percentage of shares owned by foreigner will reduce the bank performance. In addition, bank growth and bank leverage have a significant relationship with bank performance. Bank growth has a positive relationship with bank performance. Vice versa, bank leverage has a negative effect on bank performance.

Using 2006 to 2009 data, it can be summarized that the model is fit because of the $\mathrm{F}$ significant lower $(0.009)$ than $5 \%$. In addition, the $\mathrm{R}$ square indicates $58.80 \%$ which is better than previous model. This study finds two Corporate Governance variables ( $\mathrm{FaO}$ and FO) have a significant and negative effect on bank performance at $10 \%$. Family ownership has a negative effect on performance which means that the higher the family ownership the lower the bank performance. Further, the foreign ownership also has a negative effect on the bank performance which means that the higher the foreign ownership the lower the bank performance. Vice versa, the bank growth and bank leverage have a positive and negative effect respectively on bank performance. The detail result could be found in Table 5 below.

From Table 6, the second model of MRA is by adding audit quality variable into model. As previous model, this model also is divided into pre (2006 and 2007), during crisis (2008 and 2009), and (2006-2009). The detail of result could be seen in Table 6. The 2006 data, the $\mathrm{F}$ significant is greater than $10 \%$. It can be concluded that the model is not fit. Meanwhile, R square of model indicates that $40.10 \%$ variation of bank performance is determined by independent variables. All Corporate Governance variables are not significant on bank performance. Only one control variable (bank leverage) has a significant and negatively relationship with bank performance. The 2007 data is also not feasible with the $\mathrm{R}$ square $46.20 \%$. All Corporate Governance variables are also not significant on bank performance. Furthermore bank growth has a significant and positive effect on company performance. However, bank leverage has a significant and negative impact on bank performance. Thus, it can be summarized that Corporate Governance has no impact on bank performance pre-crisis 2008.

During financial crisis (2008 and 2009), it indicates that the model is fit due to $\mathrm{F}$ significant greater $(0.092)$ than $10 \%$ in 2008 . In addition, the $\mathrm{R}$ square is $48.20 \%$. Following prior result of pre-crisis, Corporate Governance also no relationship with bank performance during financial crisis in 2008. However, Bank growth and bank leverage also have positive and negative effect on bank performance. In 2009, the model is feasible ( $F$ significant 0.004 ) with $R$ square is $66.00 \%$. In contrast to 2008 , there are two Corporate Governance variables significantly affecting bank performance: one from internal mechanism (FO) and the other is external mechanism (AQ). Foreign ownership has a negative effect on bank performance. It implies that foreign ownership do not bring a positive impact on bank performance during crisis. However, audit quality as measured by Big-4 has a positive effect on bank performance. It indicates that banks are audited by Big-4 audit firm tends to have a positive impact on bank performance during crisis. For control 
Table 6: Result of MRA 2 Regression

\begin{tabular}{|c|c|c|c|c|c|c|c|c|c|c|}
\hline \multirow[t]{2}{*}{ Variable } & \multicolumn{2}{|c|}{$\begin{array}{c}\text { Pre-crisis } \\
2006\end{array}$} & \multicolumn{2}{|c|}{2007} & \multicolumn{2}{|c|}{$\begin{array}{c}\text { During- crisis } \\
2008\end{array}$} & \multicolumn{2}{|c|}{2009} & \multicolumn{2}{|c|}{ All Data } \\
\hline & Coef & t-sta & Coef & t-sta & Coef & t-sta & Coef & t-sta & Coef & t-sta \\
\hline Constant & 9.940 & 3.933 & 9.310 & 3.870 & 10.530 & 2.920 & 14.050 & 4.680 & 11.650 & 4.650 \\
\hline $\mathrm{BO}$ & -0.030 & -0.423 & 0.060 & 0.760 & 0.040 & 0.370 & -0.050 & -0.590 & 0.050 & 0.670 \\
\hline $\mathrm{FaO}$ & 0.010 & 0.239 & -0.050 & -1.320 & -0.070 & -1.300 & -0.050 & -0.950 & -0.070 & -1.560 \\
\hline FO & 0.000 & -0.091 & -0.020 & -0.790 & -0.050 & -1.130 & -0.070 & $-2.120^{* *}$ & -0.070 & $-2.070^{*}$ \\
\hline BS & 0.000 & -0.317 & 0.000 & -0.090 & 0.000 & -0.680 & 0.000 & -1.160 & 0.000 & -1.000 \\
\hline BA & -0.040 & -1.307 & -0.020 & -0.750 & 0.020 & 0.360 & 0.000 & -0.090 & -0.010 & -0.520 \\
\hline$B G$ & 0.030 & 0,639 & 0.070 & $2.600^{* *}$ & 0.130 & $2.740^{* *}$ & 0.230 & $4.140^{* * *}$ & 0.210 & $4.030^{* * *}$ \\
\hline$B L$ & -0.100 & $-2.840^{\star * *}$ & -0.080 & $-2.340^{* *}$ & -0.100 & $-1.920^{*}$ & -0.150 & $-3.440^{\star * *}$ & -0.120 & $-3.520^{* * *}$ \\
\hline$A Q$ & 2.160 & 1.060 & 1.160 & 0.660 & 1.440 & 0.590 & 5.240 & $2.380^{* *}$ & 3.240 & 1.650 \\
\hline $\mathrm{N}$ & \multicolumn{2}{|c|}{27} & \multicolumn{2}{|c|}{27} & \multicolumn{2}{|c|}{27} & \multicolumn{2}{|c|}{27} & \multicolumn{2}{|c|}{27} \\
\hline R Square & \multicolumn{2}{|c|}{0.401} & \multicolumn{2}{|c|}{0.462} & \multicolumn{2}{|c|}{0.482} & \multicolumn{2}{|c|}{0.660} & \multicolumn{2}{|c|}{0.643} \\
\hline $\begin{array}{c}\text { Adj R } \\
\text { Square }\end{array}$ & \multicolumn{2}{|c|}{0.134} & \multicolumn{2}{|c|}{0.223} & \multicolumn{2}{|c|}{0.252} & \multicolumn{2}{|c|}{0.509} & \multicolumn{2}{|c|}{0.484} \\
\hline F statistic & \multicolumn{2}{|c|}{1.504} & \multicolumn{2}{|c|}{1.931} & \multicolumn{2}{|c|}{2.096} & \multicolumn{2}{|c|}{4.367} & \multicolumn{2}{|c|}{4.044} \\
\hline F sig & \multicolumn{2}{|c|}{0.224} & \multicolumn{2}{|c|}{0.117} & \multicolumn{2}{|c|}{0.092} & \multicolumn{2}{|c|}{0.004} & \multicolumn{2}{|c|}{0.007} \\
\hline
\end{tabular}

Note: ${ }^{*},{ }^{* *}$, and ${ }^{* * *}$ indicate that a significant at $10 \%, 5 \%$, dan $1 \%$ level.

variable, bank growth and bank are also found a positive and negative effect on bank performance.

Using all data 2006-2009 is quite fit due to $F$ significant value is far lower than $5 \%$. In addition, $\mathrm{R}$ square is $64.30 \%$ which means that variation in bank performance could be explained $64.30 \%$ by independent variables. Only one of Corporate Governance variables (FO) has a significant and negatively effect on bank performance. Control variables, such as bank growth and bank leverage also have a significant relationship with bank performance. Therefore, it can be concluded that the higher the bank growth, the higher the bank performance. Meanwhile, the higher the bank leverage the lower the bank performance. There are some conclusions that it can be made based on the result of first and second MRA model above. First, there is no role of Corporate Governance on bank performance, pre-crisis (2006 and 2007) and during crisis (2008). Furthermore, Corporate Governance begins to play a little bit significant role in determining of bank performance in 2009. There is a significant and negative relationship between foreign ownership and bank performance. Vice versa, audit quality has a significant and positive impact on bank performance.

Table 7 shows the third MRA which is by adding the interaction term to result the moderating effect of the audit quality on the relationship between Corporate Governance and bank performance. Using 2006, the data is not feasible due to the $\mathrm{F}$ significant is greater than $10 \%$. In addition, the $\mathrm{R}$ square is $57.80 \%$ which indicates that variation of bank performance is explained by independent variables and the rest is explained by other variable which is not included in the model. Surprisingly, the audit quality has a significant effect on bank performance. Another word, the bank which is audited by Big-4 audit firm would be tending to increase the bank performance. In addition, the audit quality is also successfully moderating the relationship between foreign ownership and bank performance. It means that bank which is audited by Big-4 audit firm tends to weaken the relationship between foreign ownership and bank performance.

Using the 2007 data result that the model is not feasible due to the value of $F$ significant is greater than $5 \%$. In addition, $\mathrm{R}$ square is $53.90 \%$ which means that variation in dependent variable is explained $53.90 \%$ by independent variables and the rest could not explained by independent variables. The result of regression show that there is no Corporate Governance variables significantly effect on bank performance. Bank growth and bank leverage, however, have a significant relationship with bank performance. Bank growth has a positive effect on bank performance and bank leverage negatively influence bank performance. 
Table 7 notes $F$ significant value indicates that the model is not fit because of higher than $10 \%$ for 2008 period. In addition, the value of $\mathrm{R}$ square is $52.50 \%$ which means that variation of bank performance is explained $52.50 \%$ by independent variables. Like previous 2007 model, Corporate Governance variables do not have a significant relationship with bank performance. However, two control variables have a significant relationship with bank performance. Bank growth has a positive significantly effect on bank performance and bank leverage has a negative relationship with bank performance during crisis (2008).

In period of 2009, the data is fit due to lower $F$ significant $(0.01)$ than $5 \%$. In addition, $R$ square is also quite good because of $81.10 \%$ bank performance could be explained by independent variables. Corporate Governance variable that influence the bank performance is audit quality (external mechanism). Audit quality also has a positively significant relationship with bank performance and it means that the bank audited by Big- 4 audit firm tends to have a higher bank performance. For moderating effect, audit quality weakens the relationship between family ownership and bank performance. In addition, audit quality also weakens the relationship foreign ownership and bank performance. Three control variables also have a significant relationship with bank performance. First, bank size has a negatively significant effect on bank performance which means that the bigger the bank the lower the performance.

Second, bank growth has a positively and significant effect on bank performance which implies that the higher the bank growth the higher the bank performance. Finally, bank leverage has a negatively significant relationship with bank performance.

While using all data (2006 to 2009) indicate that the model is feasible and R square is $68.70 \%$. However, there are no significant Corporate Governance variables affecting on bank performance. In fact, there is also no role of audit quality as moderating variables. However, there are two control variable affecting bank performances: bank growth and bank leverage. Bank growth has a positive effect on and meanwhile, bank leverage has a negative relationship with bank performance.

Based on the final MRA model, it can be concluded that there is no role of Corporate Governance pre-crisis

Table 7: Results of MRA 3 Regression

\begin{tabular}{|c|c|c|c|c|c|c|c|c|c|c|}
\hline \multirow[t]{2}{*}{ Variable } & \multicolumn{2}{|c|}{$\begin{array}{c}\text { Pre-crisis } \\
2006\end{array}$} & \multicolumn{2}{|c|}{2007} & \multicolumn{2}{|c|}{$\begin{array}{c}\text { During crisis } \\
2008\end{array}$} & \multicolumn{2}{|c|}{2009} & \multicolumn{2}{|c|}{ All Data } \\
\hline & Coef & t-sta & Coef & t-sta & Coef & t-sta & Coef & t-sta & Coef & t-sta \\
\hline Constant & 5.340 & 1.670 & 7.560 & 2.590 & 8.600 & 2.020 & 9.230 & 3.230 & 10.820 & 3.060 \\
\hline $\mathrm{BO}$ & -0.060 & -0.750 & 0.020 & 0.240 & -0.010 & -0.070 & -0.120 & -1.380 & 0.000 & -0.020 \\
\hline $\mathrm{FaO}$ & 0.040 & 0.770 & -0.010 & -0.220 & -0.010 & -0.090 & 0.030 & 0.520 & -0.010 & -0.170 \\
\hline FO & 0.110 & 1.750 & 0.010 & 0.140 & 0.000 & -0.050 & 0.000 & -0.090 & -0.070 & -0.980 \\
\hline BS & 0.000 & 0.060 & 0.000 & -0.350 & 0.000 & -0.820 & 0.000 & $-2.390^{* *}$ & 0.000 & -1.150 \\
\hline BA & -0.030 & -0.850 & -0.030 & -0.900 & 0.010 & 0.11 & 0.000 & -0.100 & -0.030 & -0.830 \\
\hline BG & 0.000 & -0.050 & 0.070 & $2.100^{* *}$ & 0.120 & $2.090^{* *}$ & 0.170 & $3.260^{* * *}$ & 0.200 & $2.940^{* * *}$ \\
\hline$B L$ & -0.070 & -1.65 & -0.070 & $-2.150^{* *}$ & -0.100 & $-1.880^{*}$ & -0.120 & $-3.200^{\star * *}$ & -0.130 & $-3.390^{\star * *}$ \\
\hline$A Q$ & 6.720 & $2.410^{\star *}$ & 4.190 & 1.440 & 6.300 & 1.220 & 16.190 & $4.420^{\star * *}$ & 5.790 & 1.410 \\
\hline$B O \times A Q$ & -1.170 & -0.580 & 1.220 & 0.660 & -0.970 & -0.300 & 4.060 & 0.470 & 0.150 & 0.060 \\
\hline $\mathrm{FaO} \times \mathrm{AQ}$ & -0.110 & -1.490 & -0.090 & -1.370 & -0.120 & -1.030 & -0.200 & $-2.450^{\star *}$ & -0.110 & -1.320 \\
\hline FOxAQ & -0.150 & $-2.060^{* *}$ & -0.050 & -0.850 & -0.060 & -0.780 & -0.180 & $-3.310^{* * *}$ & 0.000 & 0.000 \\
\hline $\mathrm{N}$ & \multicolumn{2}{|c|}{27} & \multicolumn{2}{|c|}{27} & \multicolumn{2}{|c|}{27} & \multicolumn{2}{|c|}{27} & \multicolumn{2}{|c|}{27} \\
\hline R Square & \multicolumn{2}{|c|}{0.578} & \multicolumn{2}{|c|}{0.539} & \multicolumn{2}{|c|}{0.525} & \multicolumn{2}{|c|}{0.811} & \multicolumn{2}{|c|}{0.687} \\
\hline Adj R Square & \multicolumn{2}{|c|}{0.269} & \multicolumn{2}{|c|}{0.202} & \multicolumn{2}{|c|}{0.177} & \multicolumn{2}{|c|}{0.673} & \multicolumn{2}{|c|}{0.458} \\
\hline F statistic & \multicolumn{2}{|c|}{1.869} & \multicolumn{2}{|c|}{1.597} & \multicolumn{2}{|c|}{1.508} & \multicolumn{2}{|c|}{5.861} & \multirow{2}{*}{\multicolumn{2}{|c|}{$\begin{array}{l}2.999 \\
0.025\end{array}$}} \\
\hline F sig & \multicolumn{2}{|c|}{0.129} & \multicolumn{2}{|c|}{0.197} & \multicolumn{2}{|c|}{0.226} & \multicolumn{2}{|c|}{0.010} & & \\
\hline
\end{tabular}

Note: ${ }^{*},{ }^{* *}$, and ${ }^{* \star *}$ indicate a significant at $10 \%, 5 \%$, dan $1 \%$ level 
and during crisis (2008). However, the role of Corporate Governance is obvious in 2009. Significant Governance variables are represented by audit quality. In contrast to the expectation, audit quality weakens the relationship internal Corporate Governance mechanism (family ownership and foreign ownership). This study aims to investigate the role of Corporate Governance pre and during global financial crisis. Base on the three main models, we can conclude that there is no role of Corporate Governance in pre-global financial crisis and therefore, bank listed in Indonesia stock exchange did not have a defend tools to fight against crisis. During global financial crisis, Corporate Governance did not also play a significant role especially in 2008. Corporate Governance gives a little role in determining the bank performance in 2009.

\subsection{Discussion}

This paper aims to investigate whether there is a role of Corporate Governance pre and during global financial crisis 2008 among banks in Indonesia. This research uses three models (moderated regression analysis) using 2006, 2007, 2008 and 2009 year data. Besides, it is also analyzed using all data. In addition, two Corporate Governance mechanisms are applied that is internal mechanism (ownership) and external mechanism (audit quality). The result shows that there is no role of Corporate Governance in pre-crisis (2006 and 2007) among banking companies. In fact, there is also no role of Corporate Governance during crisis, especially in 2008. However, its role is obvious in 2009 in which there are evidenced by significant and negative effect of foreign ownership on bank performance for the first and MRA model. Further, foreign ownership and audit quality also have a significant relationship with bank performance in the second MRA model. Thus, audit quality is successfully moderating the relationship between family ownership and bank performance as well as foreign ownership. In brief, it can be concluded that a poor Corporate Governance role during global financial crisis among banking companies in Indonesia.

There are few previous researches investigating the role of Corporate Governance in financial crisis (e.g., Grove et al., 2011; Yeh et al., 2011; McNulty et al., 2013; Van-Essen et al., 2013; Srivastava, 2015; and Aldamen and Duncan, 2016). In contrast to the result of Aldamen and Duncan (2016), they find that good corporate governance play an important role in during global financial crisis 2008. In addition, Srivastava (2015) also find a different result compared to these findings. This finding is not consistent with finding of Yeh et al. (2011) which conclude that there is role of Corporate Governance during crisis. However, they use 20 largest financial institutions from G8 countries and documented that the performance during 20072008 global financial crisis period is higher for institutions with more independent directors on auditing and risk committee.

Like Yeh et al. (2011), this finding is also contradicting to the previous study done by Grove et al. (2011) which conclude that there is a role of Corporate Governance among banking companies during crisis in USA even though there is a little implementation of Corporate Governance principles. This condition cause higher agency cost and it, therefore, reduce the performance. This finding also differ from other previous research, such as McNulty et al. (2013) which using board process during financial crisis and they conclude that there is a role of Corporate Governance on performance during crisis. Finally, Van-Essen et al. (2013) also documented that there is a role of Corporate Governance on performance in Europe. They use CEO duality and incentive as Corporate Governance variables. Based on the previous research findings, it can be concluded that Corporate Governance play a significant role in global financial crisis but it is not a case among banking companies in Indonesia. Corporate Governance practice in Indonesia is low quality, especially pre-crisis. Therefore, the performance of Indonesia's bank in 2008 is low due to higher agency cost.

\section{CONCLUSION}

Global financial crisis 2008 was driven by US credit crunch and it effect countries which have economic relationship with US including Indonesia. In Indonesia, there are many banks experiencing low performance. In fact, Century Bank was in scandal and central government helps this bank. Premise is that if there is a role of Corporate Governance in global financial crisis so that bank would survive during the crisis. This study uses twenty seven (27) banks listing in Indonesia Stock Exchange. Data from 2006 to 2009 are applied to analyses the hypothesis: Corporate Governance is found no significant effect on bank performance in the pre-crisis period (2006 and 2007) and poor during global financial crisis 2008, particularly 2009. Moderated Regression Analysis is used to see the interaction of internal (ownership) and external (audit quality) of Corporate Governance mechanism. 
The result of this work shows that there is no role of Corporate Governance to improve bank performance in pre global financial crisis 2008. However, the role of Corporate Governance is still left behind in the year 2009. This finding implies that bank must improve the implementation of better Corporate Governance, even in financial crisis happen in order to survive during the crisis. This result contributes to the agency theory (Jensen and Meckling, 1976) which posits that the opportunistic of manager (e.g., Chia et al., 2007) increase during financial crisis due to their fright of the company's bankruptcy because of financial crisis. Therefore, they would undertake to increase their welfare. With the unique system characteristic of Indonesia's environment will bring to the unique contribution to the theory of Corporate Governance. Even though Indonesia follows the Continental European of Corporate Governance system, the appointing and dismissal of board are difference compared to the original system of Continental European. The future research could consider other corporate governance variables, such as board independent characteristics and audit committee characteristic.

\section{REFERENCES}

Abidin, S., Ahmad-Zaluki, N. A., \& Ilona, D. (2011). Board Quality and the Performance of Indonesian Listed Companies. Corporate Board: Role, Duties \& Composition, 7(1), 57-65. https://doi.org/10.22495/cbv7i1art5

Aldamen, H. \& Duncan, K. (2016). Does Good Corporate Governance Enhance Accruals Quality During Financial Crisis. Managerial Auditing Journal, 31(4) \&(5), 434-457. https://doi.org/10.1108/MAJ-06-2015-1206

Almutairi, A. R. (2013). The impact of Institutional Ownership and Corporate Debt on Audit Quality. Journal of Economic and Administrative Sciences, 29(2), 134-152. https://doi.org/10.1108/JEAS-09-2013-0031

Arora, P., \& Dharwadkar, R. (2011). Corporate Governance and Corporate Social Responsibility (CSR): The Moderating Roles of Attainment Discrepancy and Organization Slack. Corporate Governance: An International Review, 19(2), 136152.

https://doi.org/10.1111/j.1467-8683.2010.00843.x

Baysinger, B. D. \& Butler, H. N. (1985). Corporate Governance and the Board of Directors: Performance Effects of Changes in Board Composition. Journal of Law, Economics, \& Organization, 1(1), 101-124.

Berle, A. A. \& Means, G. C. (1932). The Modern Corporation and Private Property. New York.

Bozec, R. (2005). Boards of Directors, Market Discipline and Firm Performance. Journal of Business Finance \& Accounting, 32(9) \& (10), 1921-1960. https://doi.org/10.1111/j.0306-686X.2005.00652.x

Byrd, J., Parrino, R., \& Pritsch, G. (1998). Stockholder-Manager Conflicts and Firm Value. Financial Analysts Journal, 54(3), 14-30.

https://doi.org/10.2469/faj.v54.n3.2177
Chia, Y. M., Lapsley, I., \& Lee, Hing-Wah. (2007). Choice of Auditors and earnings Management during the Asian Financial Crisis. Managerial Auditing Journal, 22(2), 177-196. https://doi.org/10.1108/02686900710718672

Daily, C. M., Dalton, D. R., \& Cannella, Jr. A. A. (2003). Corporate Governance: Decades of Dialogue and Data. Academy of Management Review, 28(3), 371-382. https://doi.org/10.5465/amr.2003.10196703

Darmadi, S. (2016). Ownership Concentration, Family Control, and Auditor Choice Evidence from an Emerging Market. Asian Review of Accounting, 24(1), 19-42. https://doi.org/10.1108/ARA-06-2013-0043

Darmadi, S., \& Sodikin, A. (2013). Information Disclosure by Family Control Firms: the Role of Board Independence and Institutional Ownership. Asian Review of Accounting, 21(3), 223-240. https://doi.org/10.1108/ARA-01-2013-0009

Davis, J. H., Schoorman, F. D., \& Donaldson, L. (1997). Toward a Stewardship Theory of Management. Academy of Management Review, 22(1), 20-47. https://doi.org/10.5465/amr.1997.9707180258

DeAngelo, L. E. (1981). Auditor size and auditor quality. Journal of Accounting and Economics, 3, 183-99. https://doi.org/10.1016/0165-4101(81)90002-1

DeFond, M. L., \& Jiambalvo, J. (1993). "Factors Related to AuditorClient Disagreement Over Income-Increasing Accounting Methods". Cotemporary Accounting Research, 9, 415-431. https://doi.org/10.1111/j.1911-3846.1993.tb00889.x

Demsetz, H. \& Lehn, K. (1985). The Structure of Corporate Ownership: Cause and Consequences. Journal of Political Economy, 93(6), 1155-1177. https://doi.org/10.1086/261354

Denis, D. K. (2001). Twenty-Five Years of Corporate Governance Research and Counting. Review of Financial Economics, 10, 191-212. https://doi.org/10.1016/S1058-3300(01)00037-4

Faccio, M. \& Lang, L. H. P. (2002). The Ultimate Ownership of Western European Corporations. Journal of Finance Economics, 65, 365-395. https://doi.org/10.1016/S0304-405X(02)00146-0

Gul, F. A., Kim, Jeong-Bon, and Qiu, A. A. (2010). Ownership Concentration, Foreign Shareholding, Audit Quality and Stock Price Synchronicity: Evidence from China. Journal of Financial Economics, Journal of Financial Economics, 95, 425-442. https://doi.org/10.1016/j.jfineco.2009.11.005

Grove, H., Patelli, L., Victoravich, L. M., \& Xu, P (Tracy) (2011). Corporate Governance and Performance in the Wake of the Financial Crisis: Evidence from US Commercial Banks. Corporate Governance: An International Review, 19(5), 418436. https://doi.org/10.1111/j.1467-8683.2011.00882.x

Haniffa, R. \& Hudaib, M. (2006). Corporate Governance Structure and Performance of Malaysian Listed Companies. Journal of Business Finance \& Accounting, 33(7) \& (8), 1034-1062. https://doi.org/10.1111/j.1468-5957.2006.00594.x

Hashim, H., A. (2011). Corporate Disclosures by family firms: Malaysia Evidence. Journal of Business and Policy Research, 6(2), 111-125.

Haspeslagh, P. (2010). Corporate Governance and the Current Crisis. Corporate Governance. 10(4), 375-377. https://doi.org/10.1108/14720701011069614

Husnin, A. I. and Nawawi, A. (2016). Corporate Governance and Auditor Quality. Asian Review of Accounting, 24(2). 202-230. https://doi.org/10.1108/ARA-11-2013-0072

Jensen, M. C. \& Meckling, W. H. (1976). Theory of the Firm: Managerial Behavior, Agency Costs, and Ownership Structure. Journal of Financial Economics, 3(4), 306-360. https://doi.org/10.1016/0304-405X(76)90026-X 
Joh, S. W. (2003). Corporate Governance and Firm Profitability: Evidence from Korea Before the Economic Crisis. Journal of Financial Economics, 68, 287-322. https://doi.org/10.1016/S0304-405X(03)00068-0

Jung, Jin-Young. (2013). Post-Crisis Restructuring of the Corporate Governance of Korean Companies. Corporate Governance, 13(1), 3-17. https://doi.org/10.1108/14720701311302387

Kowalewski, O. (2016). Corporate Governance and Corporate Performance: Financial Crisis (2008). Management Research Review, 39(11), 1494-1515. https://doi.org/10.1108/MRR-12-2014-0287

La Porta, R., Lopez-de-Silanes, F., Shleifer, A., \& Vishny, R. (1998). Law and Finance. Journal of Political Economy, 106, 11131155. https://doi.org/10.1086/250042

La Porta, R., Lopez-de-Silanes, F., Shleifer, A., \& Vishny, R. (2000). Agency Problems and Dividend Policies around the World. Journal of Finance, 55(1), 1-33. https://doi.org/10.1111/0022-1082.00199

Liu, M., \& Magnan, M. (2011). Self-dealing Regulations, Ownership Wedge, and Corporate Valuation: International Evidence. Corporate Governance: An International Review, 19(2), 99115. https://doi.org/10.1111/j.1467-8683.2010.00839.x

Lemmon, M., L. \& Lins, K., V. (2003). Ownership Structure, Corporate Governance, and Firm Value: Evidence from the East Asian Financial Crisis. The Journal of Finance, 58(4), 1445-1468. https://doi.org/10.1111/1540-6261.00573

Lodh, S., Nandy, M., \& Chen, J. (2014). Innovation and Family Ownership; Empirical Evidence from India. Corporate Governance: An International Review, 22(1), 4-23. https://doi.org/10.1111/corg.12034

McNulty, T., Florackis, C., \& Ormrod, P (2013). Boards of Directors and Financial Risk during the Credit Crisis. Corporate Governance: An International Review, 21(1), 58-78. https://doi.org/10.1111/corg.12007

Monks, R. A. G., \& Minow, N. (2008). Corporate Governance (4th edition) Wiley, Chichester.

Nuryanah, S. \& Islam, S. M. N. (2011). Corporate Governance and Performance: Evidence from an Emerging Market. Malaysian Accounting Review, 10(1), 17-42.
Orazalin, N., Mahmood, M., \& Lee, K. J. (2016). Corporate Governance, 16(5), 798-814. https://doi.org/10.1108/CG-10-2015-0145

Really,F., K., \& Brown, K., C. (2003). Investment Analysis and Portfolio Management, 7 Edition. Ohio, Thomson SouthWestern.

Srivastava, N. K. (2015). Does Governance Structure Have any Effect on Firm Performance During the Financial Crisis Evidence from Selected Indian Companies. Journal of Strategy and Management, 8(4), 368-383. https://doi.org/10.1108/JSMA-02-2015-0014

Van-Essen, M., Engelen, Peter-Jan, \& Carney, M. (2013). Does "Good" Corporate Governance Help in a risis? The Impact of Country- and Firm-Level Governance Mechanisms in the European Financial Crisis. Corporate Governance: $A n$ International Review, 21(3), 201-224. https://doi.org/10.1111/corg.12010

Weir, C., Laing, D. \& McKnight, P. J. (2002). Internal and External Governance Mechanisms: Their Impact on the Performance of Large UK Public Companies. Journal of Business Finance \& Accounting, 29(5) \& (6), 579-611. https://doi.org/10.1111/1468-5957.00444

White, H. (1980). A Heteroscedasticity-consistent Covariance Matrix Estimator and a Direct Test for Heteroscedasticity, Econometrica, 48(4), 817-838. https://doi.org/10.2307/1912934

Yeh, Yin-Hua., Chung. H., \& Liu, Chih-Liang (2011). Committee Independence and Financial Institution Performance during the 2007-08 Credit Crunch: Evidence from a Multi-country Study. Corporate governance: An International Review, 19(5), 437-458. https://doi.org/10.1111/j.1467-8683.2011.00884.x

Zaitul, \& Ilona, D. (2018). Gender in Audit Committee and Financial Reporting Timeliness: the Case of Unique Continental European Model. International Journal of Engineering \& Technology, 7(2.29), 436-442. https://doi.org/10.14419/ijet.v7i2.29.13668

Zaitul, \& Ilona, D. (2019). Tax Aggressiveness and Politically Connected Company. In The 1st Economics, Law, Education and Humanties Internaltional Conference (Vol. 2019, pp. 1019). https://doi.org/10.18502/kss.v3i14.4294

\section{DOI: https://doi.org/10.6000/1929-7092.2019.08.54}

(c) 2019 Zaitul et al.; Licensee Lifescience Global.

This is an open access article licensed under the terms of the Creative Commons Attribution Non-Commercial License (http://creativecommons.org/licenses/by-nc/3.0/) which permits unrestricted, non-commercial use, distribution and reproduction in any medium, provided the work is properly cited. 